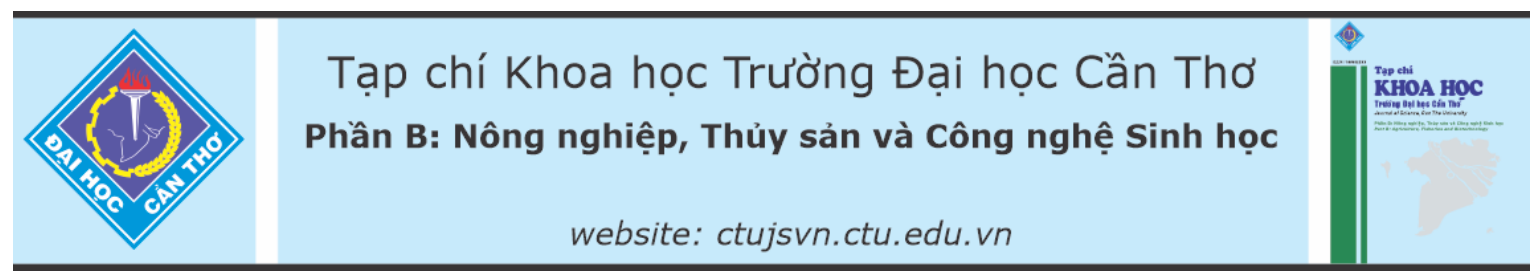

DOI:10.22144/ctu.jvn.2021.176

\title{
ĐÁNH GIÁ NĂNG SUÂT, THÀNH PHẦN SŨ̃A VÀ TÌNH TRẠNG DINH DƯỡNG CỦA ĐÀN BÒ SŨA NUÔI TẠI NÔNG HỘ THÀNH PHỐ CẦn THƠ
}

\author{
Lâm Phước Thành* \\ Bộ môn Chăn nuôi, Khoa Nông nghiệp, Truờng Đại học Cần Tho \\ *Ngưòi chịu trách nhiệm về bài viết: Lâm Phước Thành (email: phuocthanh@ctu.edu.vn)
}

\section{Thông tin chung:}

Ngày nhận bài: 02/06/2021

Ngày nhận bài sủa: 07/08/2021

Ngày duyệt đăng: 25/12/2021

\section{Title:}

Evaluating milk yield, milk composition and nutrient status of lactating dairy cows raised at small-holder farms in Can Tho city

\section{Tù khóa:}

Bò sũa, khẩu phần, năng suất sũa, thành phần sữa, tình trạng dinh duõng

\section{Keywords:}

Dairy cows, diet, milk composition, milk yield, nutrient status

\begin{abstract}
This study aimed to evaluate milk yield, milk composition and nutrient status of lactating dairy cows raised at small-holder farms in Can Tho city, and to provide re-formulated diets which were suitable for these cows. The study was carried out in 35 farms, in which 10 representative farms were collected for sampling. The result showed that all cows were crossbred HF breed, $\geq F 2$, produced $13.2 \mathrm{~kg}$ milk/day and had high milk fat $(4,03-4,84 \%)$, but these values showed high fluctuation among cows and farmers. Intakes of DM, CP and $N E_{L}$ were $15.4 \mathrm{~kg} / \mathrm{d}, 2.38 \mathrm{~kg} / \mathrm{d}$ and 19.7 MCal/d, respectively. However, feed cost of cows in this study was still high, 73,254 VND/day. Six re-formulated diets met nutrient requirement for lactating cows based on standard of NRC in 2001, and could reduce 7.17-20.8\% feed cost. In conclusion, investigated cows produced high milk yield and composition, fed enough nutrients, but feed cost was still high. The use of re-formulated diets might help to maintain great milk yield and composition while allowing reduction in feed cost.
\end{abstract}

\section{TÓM TẮT}

Mục tiêu đề tài nhằm đánh giá năng suất, thành phần sũa, tình trạng dinh duõng và đề xuất khẩu phần (KP) điều chỉnh phù hợp cho bò sũa nuôi tại nông hộ ở thành phố Cần Tho: Khảo sát được tiến hành trên 35 hộ, trong đó chọn 10 hộ để lấy mẫu. Kết quả cho thấy đàn bò thuộc giống lai $H F$, tù $F 2$ trở lên, năng suất sũa 13,2 kg/ngày và tỉ lẹ mõ sũa cao (4,034,84\%), nhung biến động lớn giũa các cá thể bò và nông hộ. Bò tiêu thu lương $D M, C P$ và $N E_{L}$, lần lượt là $15,4 \mathrm{~kg} / \mathrm{ngày}, 2,38 \mathrm{~kg} /$ ngày và 19,7 MCal/ngày. Chi phí thức ăn của bò còn khá cao (73.254 VND/ngày). Sáu KP điều chinh đáp ứng nhu cầu dinh duõng cho bò sũa theo tiêu chuẩn của NRC năm 2001 và giảm 7,17-20,8\% chi phí thức ăn. Kết luận, đàn bò có năng suất và chất luợng sũa khá tốt, tiêu thu duõong chất đáp úng nhu cầu, nhưng chi phí thức ăn còn tuoong đối cao. Các KP điều chỉnh được áp dụng có thể giúp ổn định tốt năng suất, chất luợng sũa và giảm chi phí thức ăn.

\section{GIỚI THIÊU}

Hiện nay, con người đang sử dụng rất nhiều sản phẩm từ chăn nuôi, ngoài các sản phẩm từ thịt, trứng thì sữa bò và các sản phẩm từ sữa cũng là sản phẩm cung cấp nguồn dinh dưỡng rất cao cho bữa ăn hằng ngày. Để đàn bò duy trì năng suất tốt và tạo ra các 
sản phẩm từ sữa có chất lượng ổn định, các nhà chăn nuôi cần phải chăm sóc nuôi dưỡng tốt đàn bò với khẩu phần ăn hợp lý và cân đối về nhu cầu dinh dưỡng. Tại Đồng bằng sông Cửu Long (ĐBSCL) nói chung và thành phố Cần Thơ nói riêng, trong những năm gần đây ngành chăn nuôi bò sữa đã có những bước phát triển mạnh mẽ. Tuy nhiên, việc kiểm soát về dinh dưỡng, năng suất và thành phần sữa của đàn bò chưa được quan tâm đúng mức. Các nghiên cứu trước đây chủ yếu khảo sát về khả năng sinh trưởng và sản xuất sữa (Lê Văn Phong \& Nguyễn Văn Thu, 2016) hay năng suất sữa và các loại thức ăn cho bò (Lục Nhật Huy và ctv., 2016). Việc xác định đúng nhu cầu dinh dưỡng của bò sữa, đặc biệt là nhu cầu chất khô $(\mathrm{DM})$, đạm thô $(\mathrm{CP})$ và năng lượng thuần cho tiết sữa $\left(\mathrm{NE}_{\mathrm{L}}\right)$ để từ đó xây dựng khẩu phần thích hợp cho bò là hết sức quan trọng trong nghiên cứu dinh dưỡng cũng như tình trạng thực tế của các hộ chăn nuôi. Khẩu phần ăn hợp lý và ổn định sẽ giúp việc lên kế hoạch thức ăn (có kế hoạch sản xuất, thu mua, dự trữ thức ăn) tại các thời điểm thích hợp, làm giảm giá thành sản phẩm và tăng hiệu quả trong chăn nuôi (Vũ Chí Cương và ctv., 2011). Chính vì vậy, đề tài được tiến hành nhằm đánh giá hiện trạng năng suất, thành phần sữa và tình trạng dinh dưỡng của đàn bò sữa nuôi tại nông hộ thành phố Cần Thơ; trên cơ sở đó, đề xuất khẩu phần điều chỉnh cân đối với nhu cầu dinh dưỡng của đàn bò đang cho sữa và nâng cao hiệu quả kinh tế chăn nuôi cho nông hộ.

\section{VẬT LIỆU VÀ PHƯƠNG PHÁP}

\subsection{Thời gian và địa điểm}

Đề tài được thực hiện từ tháng 9/2020 đến tháng 12/2020 tại các hộ chăn nuôi bò sữa trên địa bàn thành phố Cần Thơ. Mẫu sữa và thức ăn được phân tích tại Phòng thí nghiệm Kỹ thuật nuôi gia súc nhai lại thuộc Bộ môn Chăn nuôi, Khoa Nông nghiệp, Trường Đại học Cần Thơ.

\section{2. Đối tượng và chỉ tiêu nghiên cứu}

Đối tượng nghiên cứu là bò sữa, sữa bò tươi và thức ăn cho bò tại các nông hộ chăn nuôi tại thành phố Cần Thơ.

Chỉ tiêu khảo sát trong nghiên cứu gồm có: Quy mô đàn bò sữa, năng suất sữa, thành phần sữa, lượng thức ăn và dưỡng chất tiêu thụ và xây dựng khẩu phần điều chỉnh.

\subsection{Phương pháp điều tra và lấy mẫu}

Ba mươi lăm hộ chăn nuôi bò sữa trên địa bàn thành phố Cần Thơ tại các quận/huyện gồm Cái Răng, Ninh Kiều, Bình Thủy và Phong Điền được điều tra ngẫu nhiên. Mười hộ có cơ cấu đàn và khẩu phần cho ăn điển hình được chọn đại diện cho thực trạng chăn nuôi tại thành phố Cần Thơ để đánh giá về các chỉ tiêu khảo sát. Tỷ lệ bò đang cho sữa, bò mang thai và bê cái được xác định từ số liệu trung bình của 10 hộ chăn nuồi. Năng suất sữa của đàn bò khảo sát được xác định từ số liệu ghi nhận của từng nông hộ đối với lượng sữa của từng cá thể trong 3 ngày liên tục. Thời kỳ cho sữa của từng cá thể bò được xác định bằng phỏng vấn trực tiếp, kết hợp với thông tin ghi chép của nông hộ. Ở mỗi hộ chăn nuôi, 4-5 con bò sữa được chọn ngẫu nhiên để lấy $30 \mathrm{~mL}$ sữa/con cho lần vắt sữa buổi sáng $(4: 00 \mathrm{~h})$ và chiều (15:00 h) theo TCVN 3577:1981. Mẫu sữa được trữ lạnh trong hủ nhựa chuyên dụng và mang về phòng thí nghiệm phân tích thành phần sữa ngay trong ngày. Các mẫu thức ăn được thu tại nông hộ gồm có: thức ăn hỗn hợp (TĂHH), bã bia, bã đậu nành, bã mì, trái và quầy chuối chín, thân và trái bắp ủ chua, vỏ và cùi bắp ủ chua, vỏ khóm ủ chua và cỏ voi. Bốn vị trí ở mỗi loại thức ăn được lấy ngẫu nhiên rồi trộn đều và lấy $500 \mathrm{~g} / \mathrm{loại}$ thực liệu ở mỗi hộ mang về phòng thí nghiệm phân tích thành phần hóa học.

\subsection{Phương pháp phân tích và tính toán số liệu}

Mẫu sữa được phân tích thành phần bao gồm: chất béo (fat), đạm (protein), đường (lactose), chất rắn không béo (SNF) và chât rắn tồng số (TS) bằng máy phân tích sữa tự động MilkoScan ${ }^{\mathrm{TM}}$ Mars (Foss, Đan Mạch).

Mẫu thức ăn được phân tích vật chất khô (DM), vật chất hữu cơ (OM), khoáng tổng số (Ash), đạm thô $(\mathrm{CP})$ và béo thô $(\mathrm{EE})$ theo phương pháp của AOAC (1990). Xơ trung tính (NDF) và xơ acid (ADF) được xác định theo phương pháp của Van Soest et al. (1991). Thành phần hóa học của thức ăn được tính toán và trình bày trên $\mathrm{DM}$.

Các giá trị dinh dưỡng được tính toán gồm: carbohydrate không xơ (non-fiber carbohydrate, NFC), tổng dưỡng chất tiêu hóa (total degestible nutrients, TDN), năng lượng thô (gross energy, GE), năng lượng tiêu hóa (digestible energy, DE), năng lượng trao đổi (metabolizable energy, $\mathrm{ME}$ ) và năng lượng thuần cho tiết sữa (net energy of lactation, $\mathrm{NE}_{\mathrm{L}}$ ), cụ thể như sau: 2001)

$\mathrm{NFC}(\%)=100-\mathrm{NDF}-\mathrm{CP}-\mathrm{EE}-\mathrm{Ash}(\mathrm{NRC}$,

TDN (\%, thức ăn hỗn hợp $)=0,323 \times \mathrm{NDF}+$ $0,883 \times \mathrm{NFC}+1,829 \times \mathrm{EE}+0,885 \times \mathrm{CP}$ (Jayanegara et al., 2019) 
$\operatorname{TDN}(\%$, thức ăn thô $)=0,479 \times \mathrm{NDF}+0,704 \times$ $\mathrm{NFC}+1,594 \times \mathrm{EE}+0,714 \times \mathrm{CP}($ Jayanegara et al., 2019)

$\mathrm{GE}(\mathrm{Mcal} / \mathrm{kg} \mathrm{DM})=0,056 \times \mathrm{CP}+0,094 \times \mathrm{EE}+$ $(100-\mathrm{CP}-\mathrm{EE}-\mathrm{Ash}) \times 0,042$ (Weiss \& Tebbe, 2019) 2001)

$\mathrm{DE}(\mathrm{Mcal} / \mathrm{kg} \mathrm{DM})=0,04409 \times \mathrm{TDN}(\mathrm{NRC}$, 2001)

$\mathrm{ME}(\mathrm{Mcal} / \mathrm{kg} \mathrm{DM})=\mathrm{DE} \times 1,01-0,45(\mathrm{NRC}$,

$\mathrm{NE}_{\mathrm{L}}(\mathrm{Mcal} / \mathrm{kg} \mathrm{DM})=0,0245 \times \mathrm{TDN}-0,12$ (NRC, 2001)

Khẩu phần điều chỉnh: Được xây dựng theo tiêu chuẩn của NRC (2001), sử dụng phần mềm WinFeed 2.8 (WinFeed Single Licence, Cambridge, UK).

\subsection{Xử lí số liệu}

Số liệu được tính toán trên phần mềm Microsoft Excel 2019.

\section{KẾT QUẢ VÀ THẢO LUẬN}

\subsection{Cơ cấu đàn bò sữa}

Tổng đàn bò sữa được điều tra tại 35 hộ chăn nuôi là 491 con (chiếm 34,3\% tổng đàn bò sữa của toàn thành phố Cần Thơ, với 1.432 con), trong đó 10 hộ được chọn có 210 con, trung bình mỗi hộ nuôi 21 con, hộ nuôi nhiều nhất là 31 con và ít nhất là 15 con. Trong thực tế, nông hộ tiến hành mua giống mới và bán bò cái loại thải rất thường xuyên nên không nắm được chính xác thế hệ lai của bò đang cho sữa. Tuy nhiên, qua đánh giá của nhóm điều tra thì hầu hết bò được khảo sát tại nông hộ thuộc giống lai $\mathrm{HF}$ từ $\mathrm{F} 2$ trở lên.

Hình 1 cho thấy nhóm bò đang cho sữa chiếm $40,9 \%$, kết quả này thấp hơn với điều tra của Nguyễn Hoàng Nhẩn (2013) tại hợp tác xã bò sữa Long Hòa, thành phố Cần Thơ là $52,2 \%$, nhưng lại khá tương đồng so với kết quả của Lục Nhật Huy (2016) là $43,7 \%$ điều tra tại hợp tác xã bò sữa Evergrowth tỉnh Sóc Trăng. Nhóm bò mang thai và bê cái chiếm tỷ lệ khá cao, lần lượt là 22,9 và $36,2 \%$, kết quả này cao hơn với điều tra của Lâm Phước Thành (2021) trên đàn bò sữa tại trang trại Farm Milk Cần Thơ với bò mang thai và bê cái lần lượt là 13 và $28 \%$.

\section{Bê cái $\quad$ Bò mang thai $\quad$ Bò đang cho sữa}

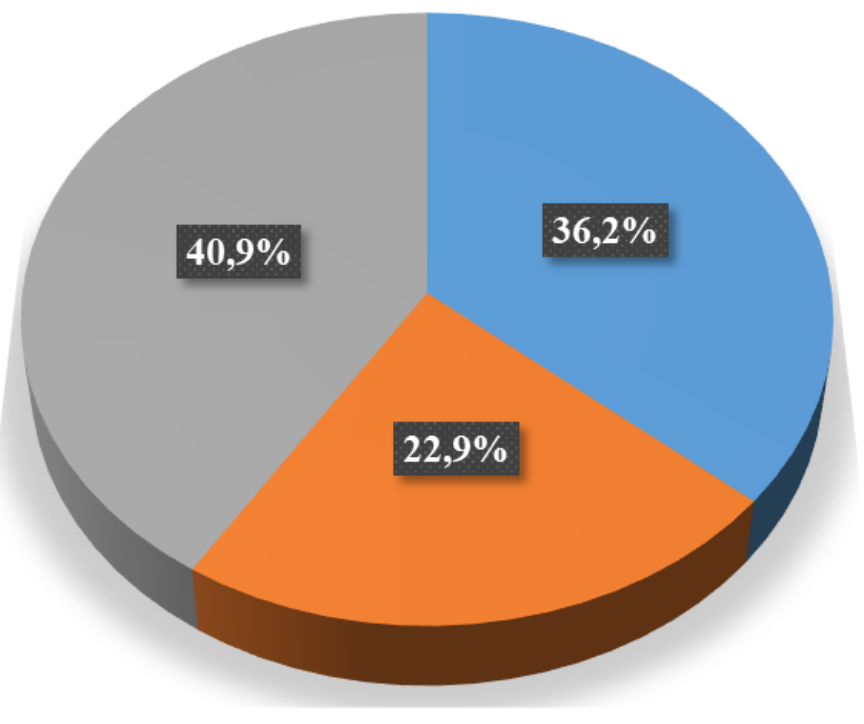

Hình 1. Cơ cấu đàn bò sữa tại nông hộ

\subsection{Năng suất và thành phần sữa}

Khảo sát 45 bò trong giai đoạn 5,22 $\pm 2,41$ tháng cho sữa tại 10 hộ chăn nuôi cho thấy năng suất sữa bình quân là $13,2 \mathrm{~kg} / \mathrm{con} /$ ngày (Bảng 1 ), kết quả này cao hơn so với kết quả khảo sát của Lê Thụy Bảo Quỳnh (2011) là từ 9,8 đến $10,8 \mathrm{~kg} / \mathrm{con} / \mathrm{ngày} \mathrm{tại}$ Hợp tác xã bò sữa Long Hòa, thành phố Cần Thơ và cao hơn so với nghiên cứu của Lục Nhật Huy (2016) 
là $11,3 \mathrm{~kg} / \mathrm{con} / \mathrm{ngày}$ khi điều tra tại Hợp tác xã bò sữa Evergrowth tỉnh Sóc Trăng. Thành phần sữa có sự chênh lệch lớn giữa buổi sáng và buổi chiều. Tỉ lệ mỡ sữa của buổi chiều $(4,84 \%)$ cao hơn buổi sáng $(4,03 \%)$. Các thành phần khác như đạm, đường, chất rắn không béo và chất rắn tổng số không có sự chênh lệch giữa buổi sáng và buổi chiều. Mỡ sữa trung bình của đàn bò khảo sát là $4,43 \%$, cao hơn nhiều so với tiêu chuẩn mỡ sữa bò loại $1(3,5 \%)$ của công ty Vinamilk. Nhiều yếu tố có thể ảnh hưởng đến hàm lượng mỡ sữa như: giống, thời kỳ cho sữa, năng suất sữa, tình trạng dinh dưỡng, khẩu phần ăn, tỷ lệ thức ăn tinh/thô và sự bổ sung dầu trong khẩu phần (Hanuš et al., 2018). Trong đó, giống và khẩu phần ăn có thể là yếu tố chính dẫn đến hàm lượng mỡ sữa cao ở đàn bò khảo sát. Đàn bò sữa nuôi ở nông hộ tại thành phố Cần Thơ được lai tạo từ tinh bò đực HF với bò cái nền giống lai Sind, có hàm lượng mỡ sữa cao so với giống bò sữa $\mathrm{HF}$ thuần chủng. Về khẩu phần ăn, tất cả các nông hộ khảo sát đều sử dụng bã bia tươi trong khẩu phần (chiếm 19,9\% $\mathrm{DM}$ ) của bò đang cho sữa, điều này đã giúp nâng cao hàm lượng mỡ sữa của của đàn bò. Belibasakis and Tsirgogianni (1996) báo cáo rằng bò sữa được bổ sung $16 \%$ bã bia tươi trong khẩu phần đã cải thiện đáng kể hàm lượng mỡ sữa. Younker et al. (1998) cho rằng lượng acid acetic sản sinh từ dạ cỏ cao đã cải thiện đáng kể hàm lượng mỡ sữa ở bò được cho ăn bã bia thay thế cho thức ăn hỗn hợp trong khẩu phần.

\section{Bảng 1. Năng suất và thành phần sữa}

\begin{tabular}{lcccc}
\hline Chỉ tiêu & $\boldsymbol{n}$ & \multicolumn{3}{c}{ TB \pm SD } \\
\hline Năng suất sữa (kg/ngày) & 45 & & $13,2 \pm 3,93$ & \\
Thành phần sữa (\%) & 90 & Sáng & Chiều & Trung bình \\
Béo & & $4,03 \pm 0,93$ & $4,84 \pm 0,98$ & $4,43 \pm 1,01$ \\
Đạm & & $3,38 \pm 0,47$ & $3,45 \pm 0,50$ & $3,42 \pm 0,48$ \\
Đường & & $4,47 \pm 0,40$ & $4,52 \pm 0,22$ & $4,50 \pm 0,32$ \\
Chất rắn không béo & & $8,64 \pm 0,50$ & $8,72 \pm 0,53$ & $8,68 \pm 0,51$ \\
Chất rắn tồng số & & $12,4 \pm 0,89$ & $13,3 \pm 1,00$ & $12,9 \pm 1,05$ \\
\hline
\end{tabular}

\subsection{Lượng ăn và dưỡng chất tiêu thụ}

\subsubsection{Thành phần hóa hoc của thức ăn sủ dụng tại nông họ}

Hàm lượng DM có vai trò quan trọng ảnh hưởng tới mức ăn, thực liệu có nhiều nước làm giảm mức ăn vào của vật nuôi, ngoài ra cũng khó bảo quản và chế biến. Hàm lượng DM của các loại thực liệu dao động từ 12,0 đến $89,6 \%$, chất hữu cơ đều đạt trên $87 \%$ (Bảng 2). Hàm lượng $\mathrm{CP}$ dao động trong khoảng 3,00-25,6\%, trong đó $\mathrm{CP}$ cao nhất ở bã bia đạt $25,6 \%$, phù hợp với kết quả của Lã Văn Kính (2003), tiếp đến là TĂHH đạt $19,3 \%$ và thấp nhất ở vỏ khóm ủ chua với 3,00\% DM. Cỏ voi có hàm lượng $\mathrm{CP}$ là $8,57 \%$, kết quả này phù hợp với nghiên cứu của Nguyễn Nhựt Xuân Dung và ctv. (2007) với $\mathrm{CP}$ của cỏ voi là $8,52 \%$. Các loại thức ăn này có hàm lượng NDF và $\mathrm{ADF}$ khá cao, mang tính đặc thù của vùng và hầu như được tận dụng tối đa ở địa phương. Hàm lượng NDF cao nhất ở bã mì $(69,9 \%)$ và thấp nhất ở bã đậu nành $(38,8 \%)$. Hàm lượng $\mathrm{ADF}$ cao nhất ở chuối chín nguyên quầy loại thải $(43,8 \%)$, không có sự khác biệt lớn về hàm lượng $\mathrm{ADF}$ của cỏ voi, bã mì, thân và trái bắp ủ chua, vỏ và cùi bắp ủ chua, vỏ khóm ủ chua, dao động từ 33,1-40,8\%. Kết quả này phù hợp với nghiên cứu của Đinh Văn Mười và ctv. (2011b) về phần thành hóa học của thức ăn thô khô, phụ phẩm nhiều xơ có hàm lượng $\mathrm{ADF}$ biến động từ $32,8-47,5 \%$. Cỏ voi có hàm lượng NFC thấp nhất $(18,9 \%)$ và cao nhất là bã đậu nành $(36,1 \%)$ vì hàm lượng NDF trong bã đậu nành tương đối thấp hơn các loại thực liệu khác. Tổng dưỡng chất tiêu hóa của bã đậu nành cao nhất $(67,7 \%)$, tiếp đến là bã bia với $64,0 \%$ và TĂHH là $59,0 \%$. Các giá trị $\mathrm{GE}, \mathrm{DE}, \mathrm{ME}$ và $\mathrm{NE}_{\mathrm{L}}$ của các thực liệu dao động lần lượt là 4,03-4,66, 2,07-2,99, 1,65-2,57 và 1,03 $1,54 \mathrm{Mcal} / \mathrm{kg}$ DM. Bã bia có năng lượng thô cao nhất $(4,66 \mathrm{Mcal} / \mathrm{kg} \mathrm{DM})$, kết quả này phù hợp với nghiên cứu Đinh Văn Mười và ctv. (2011a) là 4,58 $\mathrm{Mcal} / \mathrm{kg} \mathrm{DM}$. Bã đậu nành có các giá trị $\mathrm{DE}, \mathrm{ME}$ và $\mathrm{NE}_{\mathrm{L}}$ cao nhất trong các thực liệu $(2,99,2,57$ và 1,54 $\mathrm{Mcal} / \mathrm{kg} \mathrm{DM}$ ). Năng lượng trao đổi của bã đậu nành trong nghiên cứu này phù hợp với các nghiên cứu trước đây với giá trị $\mathrm{ME}$ của bã đậu nành là 2,332,68 Mcal/kg DM (Viện Chăn nuôii, 1995; Lã Văn Kính, 2003; Đinh Văn Mười và ctv., 2011a). 
Bảng 2. Thành phần hóa học của thức ăn (\%DM)

\begin{tabular}{lrrrrrrrrr}
\hline & TĂHH & $\begin{array}{r}\text { Bã } \\
\text { bia }\end{array}$ & $\begin{array}{r}\text { Bã đậu } \\
\text { nành }\end{array}$ & $\begin{array}{r}\text { Bã } \\
\text { mì }\end{array}$ & $\begin{array}{c}\text { Chuối } \\
\text { chín }\end{array}$ & $\begin{array}{c}\text { Cỏ } \\
\text { voi }\end{array}$ & $\begin{array}{r}\text { Vỏ khóm } \\
\text { ủ chua }\end{array}$ & \multicolumn{2}{c}{ Thân và trái Vỏ và cùi bắp } \\
bắp ủ chua & ủ chua \\
\hline $\mathrm{DM}$ & 89,6 & 23,9 & 15,2 & 13,0 & 14,7 & 16,6 & 12,0 & 20,8 & 22,3 \\
$\mathrm{OM}$ & 92,4 & 96,4 & 96,9 & 97,2 & 88,0 & 91,4 & 92,1 & 96,2 & 91,2 \\
$\mathrm{Ash}$ & 7,56 & 3,59 & 3,11 & 2,82 & 12,0 & 8,57 & 7,94 & 3,77 & 8,81 \\
$\mathrm{CP}$ & 19,3 & 25,6 & 18,0 & 4,84 & 6,48 & 8,43 & 3,00 & 7,15 & 9,86 \\
$\mathrm{NDF}$ & 47,0 & 46,2 & 38,8 & 69,9 & 51,6 & 62,7 & 55,3 & 67,7 & 54,4 \\
$\mathrm{ADF}$ & 17,9 & 28,3 & 24,1 & 38,1 & 43,8 & 40,8 & 33,1 & 39,8 & 37,5 \\
$\mathrm{EE}$ & 3,90 & 4,93 & 4,06 & 1,19 & 8,42 & 1,46 & 2,57 & 1,63 & 1,38 \\
$\mathrm{NFC}$ & 22,3 & 19,7 & 36,1 & 21,3 & 21,5 & 18,9 & 31,1 & 19,8 & 25,5 \\
$\mathrm{TDN}$ & 59,0 & 64,0 & 67,7 & 53,8 & 57,9 & 51,7 & 54,7 & 54,0 & 53,3 \\
$\mathrm{GE}^{(2)}$ & 4,35 & 4,66 & 4,53 & 4,21 & 4,22 & 4,03 & 4,04 & 4,23 & 4,04 \\
$\mathrm{DE}^{(2)}$ & 2,60 & 2,82 & 2,99 & 2,37 & 2,55 & 2,28 & 2,41 & 2,38 & 2,35 \\
$\mathrm{ME}^{(2)}$ & 2,18 & 2,40 & 2,57 & 1,95 & 2,13 & 1,85 & 1,98 & 1,96 & 1,92 \\
$\mathrm{NE}_{\mathrm{L}}^{(2)}$ & 1,33 & 1,45 & 1,54 & 1,20 & 1,30 & 1,15 & 1,22 & 1,20 & 1,19 \\
\hline
\end{tabular}

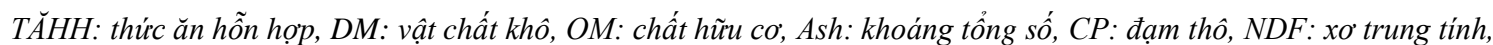
ADF: xo acid, EE: béo thô, NFC: carbohydrate không xo, TDN: tổng duõng chất tiêu hóa, GE: năng luợng thô, DE: năng luọng tiêu hóa, $M E$ : năng luợng trao đổi, $N E_{L}$ : năng luợng thuần cho tiết sũa, ${ }^{(1)}$ trái và quầy chuối chín loại thải, ${ }^{(2)}$ : Mcal/kg DM

Bảng 3. Lượng thức ăn tiêu thụ

\begin{tabular}{lccccccccccc}
\hline \multirow{2}{*}{ Chỉ tiêu } & \multicolumn{10}{c}{ Khẩu phần } \\
\cline { 2 - 12 } & KP1 & KP2 & KP3 & KP4 & KP5 & KP6 & KP7 & KP8 & KP9 & KP10 & TB \\
\hline Số thực liệu sử dụng & 4 & 5 & 5 & 5 & 5 & 5 & 6 & 6 & 6 & 7 \\
\hline Lượng tươi (kg/ngày) & & & & & & & & & & \\
\hline TĂHH & 5,8 & 4,30 & 7,50 & 6,70 & 5,60 & 6,00 & 6,30 & 2,70 & 6,30 & 8,30 & 5,95 \\
Bã bia & 10,4 & 4,67 & 6,25 & 2,22 & 17,4 & 30,0 & 6,67 & 25,0 & 18,2 & 7,69 & 12,8 \\
Bã đậu nành & - & - & - & - & 2,17 & 5,00 & - & 7,14 & 18,2 & 3,85 & 7,27 \\
Bã mì & - & - & - & - & 19,6 & - & 5,13 & 10,7 & - & - & 11,8 \\
Chuối chín (loại thải) & - & - & - & 14,8 & 20,0 & 20,0 & - & 21,4 & 18,2 & - & 18,9 \\
Cỏ voi & - & 20,0 & 18,8 & 14,8 & - & 10,0 & 15,4 & - & 9,09 & 7,69 & 13,7 \\
Vỏ khóm ủ chua & 24,4 & 22,0 & 6,25 & - & - & - & 5,13 & 7,14 & 2,73 & 7,69 & 10,8 \\
Thân và trái bắp ủ chua & - & - & 10,0 & - & - & - & 10,3 & - & - & 7,69 & 9,32 \\
Vỏ và cùi bắp ủ chua & 24,4 & 22,0 & - & 14,8 & - & - & - & - & - & 7,69 & 17,2 \\
\hline Lượng DM (kg/ngày) & & & & & & & & & & & \\
\hline TĂHH & 5,20 & 3,85 & 6,72 & 6,00 & 5,02 & 5,38 & 5,65 & 2,42 & 5,65 & 7,44 & 5,33 \\
Bã bia & 2,48 & 1,12 & 1,50 & 0,53 & 4,16 & 7,18 & 1,60 & 5,98 & 4,35 & 1,84 & 3,07 \\
Bã đậu nành & - & - & - & - & 0,33 & 0,76 & - & 1,08 & 2,76 & 0,58 & 1,10 \\
Bã mì & - & - & - & - & 2,54 & - & 0,67 & 1,39 & - & - & 1,53 \\
Chuối chín (loại thải) & - & - & - & 2,17 & 2,93 & 2,93 & - & 3,14 & 2,66 & - & 2,77 \\
Cỏ voi & - & 3,31 & 3,11 & 2,46 & - & 1,66 & 2,55 & - & 1,51 & 1,27 & 2,27 \\
Vỏ khóm ủ chua & 2,94 & 2,64 & 0,75 & - & - & - & 0,62 & 0,86 & 0,33 & 0,92 & 1,29 \\
Thân vày trái bắp ủ chua & - & - & 2,08 & - & - & - & 2,13 & - & - & 1,60 & 1,93 \\
Vỏ và cùi bắp ủ chua & 5,46 & 4,91 & - & 3,31 & - & - & - & - & - & 1,72 & 3,85 \\
\hline
\end{tabular}

\section{Luợng thức ăn tiêu thu}

Kết quả Bảng 3 cho thấy các loại thực liệu được sử dụng nhiều nhất trong các khẩu phần là $\mathrm{TA} H \mathrm{H}$, bã bia, cỏ voi và vỏ khóm ủ chua. Có 10 hộ sử dụng TĂHH của công ty CJ Vina, dao động từ 2,42-7,44 $\mathrm{kg} \mathrm{DM} /$ ngày. Lượng TĂHH được cho ăn phụ thuộc vào sản lượng sữa, những bò có năng suất sữa cao hơn sẽ cho lượng TĂHH cao hơn. Tuy nhiên, nông hộ tăng lượng TĂHH cho bò theo cảm tính, không theo 1 khuyến cáo cụ thể. Bã bia cũng được 10 hộ sử dụng với lượng ăn trung bình là $3,07 \mathrm{~kg}$ $\mathrm{DM} /$ ngày, cao nhất là $\mathrm{KP} 6$ với $7,18 \mathrm{~kg} \mathrm{DM} /$ ngày và thấp nhất là $\mathrm{KP} 4$ với $0,53 \mathrm{~kg} \mathrm{DM} / \mathrm{ngày}$. Thức ăn xanh chủ yếu là cỏ voi. Tuy nhiên, do thiếu đất trồng 
cỏ nên chỉ có 7 hộ sử dụng cỏ voi, dao động từ 1,27$3,3 \mathrm{~kg} \mathrm{DM} / \mathrm{ngày}$, cao nhất là $\mathrm{KP} 2$ với $3,31 \mathrm{~kg}$ $\mathrm{DM} /$ ngày và thấp nhất là $\mathrm{KP} 10$ với $1,27 \mathrm{~kg}$ $\mathrm{DM} /$ ngày. Tiếp đến là vỏ khóm ủ chua cũng được 7 hộ sử dụng, tuy có hàm lượng protein thấp nhưng lại có hàm lượng chất xơ, hàm lượng đường dễ hòa tan cao và giá thành thấp, trung bình mỗi hộ sử dụng $1,29 \mathrm{~kg} \mathrm{DM} /$ ngày. Bã mì, thân và trái bắp ủ chua ít được sử dụng trong khẩu phần nhất, có $3 / 10$ hộ sử dụng. Về lượng tươi, các KP5, KP6, KP8, KP9 có lượng bã bia quá cao lần lượt là 17,4, 30,0, 25,0, $18,2 \mathrm{~kg} / \mathrm{con} /$ ngày. Việc cho ăn quá nhiều bã bia (vượt quá $15 \mathrm{~kg} / \mathrm{con} / \mathrm{ngày)} \mathrm{sẽ} \mathrm{làm} \mathrm{giảm} \mathrm{tỷ} \mathrm{lệ} \mathrm{tiêu} \mathrm{hóa}$ chất xơ, các chất chứa nitơ và kéo theo sự giảm chất lượng sữa (Nguyễn Xuân Trạch \& Đinh Văn Cải, 2008).

Bảng 4. Lượng dưỡng chất tiêu thụ

\begin{tabular}{|c|c|c|c|c|c|c|c|c|c|c|c|}
\hline \multirow{2}{*}{ Chỉ tiêu } & \multicolumn{11}{|c|}{ Khẩu phần } \\
\hline & KP1 & KP2 & KP3 & KP4 & KP5 & KP6 & KP7 & KP8 & KP9 & KP10 & TB \\
\hline \multicolumn{12}{|c|}{ Dưỡng chất tiêu thụ (kg DM/con/ngày) } \\
\hline $\mathrm{DM}$ & 16,1 & 15,8 & 14,2 & 14,5 & 15,0 & 17,9 & 13,2 & 14,9 & 17,3 & 15,4 & 15,4 \\
\hline $\mathrm{OM}$ & 14,9 & 14,6 & 13,2 & 13,2 & 14,0 & 16,7 & 12,4 & 14,0 & 16,1 & 14,3 & 14,3 \\
\hline Ash & 1,20 & 1,26 & 0,97 & 1,24 & 0,96 & 1,18 & 0,85 & 0,92 & 1,14 & 1,04 & 1,08 \\
\hline $\mathrm{CP}$ & 2,26 & 1,87 & 2,11 & 1,97 & 2,41 & 3,34 & 1,91 & 2,49 & 3,01 & 2,43 & 2,38 \\
\hline $\mathrm{NDF}$ & 8,19 & 8,54 & 7,62 & 7,53 & 7,70 & 8,69 & 7,24 & 7,39 & 8,23 & 7,90 & 7,90 \\
\hline $\mathrm{ADF}$ & 4,65 & 5,07 & 3,97 & 4,41 & 4,40 & 5,13 & 3,81 & 4,57 & 4,79 & 4,09 & 4,49 \\
\hline EE & 0,48 & 0,39 & 0,43 & 0,52 & 0,69 & 0,87 & 0,39 & 0,74 & 0,80 & 0,50 & 0,58 \\
\hline NFC & 3,96 & 3,78 & 3,02 & 3,22 & 3,23 & 3,83 & 2,81 & 3,35 & 4,07 & 3,51 & 3,48 \\
\hline TDN & 9,01 & 8,47 & 7,79 & 7,97 & 8,73 & 10,7 & 7,23 & 8,89 & 10,4 & 8,71 & 8,79 \\
\hline $\mathrm{GE}^{*}$ & 68,1 & 65,9 & 60,6 & 61,1 & 65,9 & 79,4 & 56,6 & 66,0 & 76,0 & 66,2 & 66,6 \\
\hline $\mathrm{DE}^{*}$ & 39,7 & 37,3 & 34,4 & 35,2 & 38,5 & 47,3 & 31,9 & 39,2 & 45,8 & 38,4 & 38,8 \\
\hline $\mathrm{ME}^{*}$ & 32,9 & 30,6 & 28,3 & 29,0 & 32,1 & 39,7 & 26,3 & 32,9 & 38,5 & 31,9 & 32,2 \\
\hline $\mathrm{NE}_{\mathrm{L}}{ }^{*}$ & 20,1 & 18,8 & 17,4 & 17,8 & 19,6 & 24,1 & 16,1 & 20,0 & 23,4 & 19,5 & 19,7 \\
\hline \multicolumn{12}{|c|}{ Thành phần dưỡng chất của khẩu phần (\%) } \\
\hline $\mathrm{DM}$ & 24,7 & 21,7 & 29,0 & 27,1 & 23,2 & 25,2 & 27,0 & 20,1 & 23,7 & 30,4 & 25,2 \\
\hline $\mathrm{OM}$ & 92,6 & 92,1 & 93,2 & 91,5 & 93,6 & 93,4 & 93,6 & 93,8 & 93,4 & 93,2 & 93,0 \\
\hline Ash & 7,44 & 7,94 & 6,83 & 8,54 & 6,43 & 6,60 & 6,44 & 6,16 & 6,63 & 6,77 & 6,98 \\
\hline $\mathrm{CP}$ & 14,1 & 11,8 & 14,9 & 13,6 & 16,0 & 18,7 & 14,5 & 16,7 & 17,4 & 15,8 & 15,4 \\
\hline $\mathrm{NDF}$ & 50,9 & 53,9 & 53,8 & 52,0 & 51,4 & 48,5 & 54,8 & 49,7 & 47,7 & 51,4 & 51,4 \\
\hline $\mathrm{ADF}$ & 28,9 & 32,0 & 28,0 & 30,5 & 29,4 & 28,7 & 28,8 & 30,7 & 27,8 & 26,6 & 29,1 \\
\hline $\mathrm{EE}$ & 2,96 & 2,46 & 3,07 & 3,63 & 4,61 & 4,83 & 2,99 & 4,95 & 4,64 & 3,23 & 3,74 \\
\hline NFC & 24,6 & 23,9 & 21,4 & 22,2 & 21,5 & 21,4 & 21,3 & 22,5 & 23,6 & 22,8 & 22,5 \\
\hline TDN & 56,0 & 53,4 & 55,1 & 55,1 & 58,3 & 59,9 & 54,8 & 59,8 & 60,2 & 56,6 & 56,9 \\
\hline $\mathrm{GE}^{* *}$ & 4,24 & 4,16 & 4,28 & 4,22 & 4,39 & 4,44 & 4,29 & 4,43 & 4,41 & 4,30 & 4,32 \\
\hline $\mathrm{DE}^{* *}$ & 2,52 & 2,44 & 2,51 & 2,49 & 2,62 & 2,67 & 2,51 & 2,67 & 2,68 & 2,55 & 2,57 \\
\hline $\mathrm{ME}^{* *}$ & 2,09 & 2,01 & 2,09 & 2,07 & 2,20 & 2,24 & 2,09 & 2,25 & 2,26 & 2,13 & 2,14 \\
\hline $\mathrm{NE}_{\mathrm{L}}{ }^{* *}$ & 1,28 & 1,24 & 1,28 & 1,26 & 1,34 & 1,36 & 1,27 & 1,37 & 1,37 & 1,30 & 1,31 \\
\hline
\end{tabular}

TĂHH: thức ăn hốn hơp, DM: vật chất khô, OM: chất hũu co; Ash: khoáng tổng số, CP: đạm thô, NDF: xo trung tính, ADF: xo acid, EE: béo, NFC: carbohydrate không xo, TDN: tổng duõng chất tiêu hóa, GE: năng lương thô, DE: năng lượng tiêu hóa, $M E$ : năng lượng trao đổi, $N E_{L}$ : năng luợng tiết sũa, KP: khẩu phần, TB: trung bình, *: Mcal/con/ngày, **: MCal/kg DM.

\section{Luợng duõng chất tiêu thu}

Kết quả Bảng 4 cho thấy các khẩu phần có lượng DM tiêu thụ đạt từ 13,2-17,9 kg/con/ngày, kết quả này phù hợp với nghiên cứu của Lâm Phước Thành (2021), bò sữa có năng suất từ $15 \mathrm{~kg} /$ ngày trở xuống tiêu thụ $16,6 \mathrm{~kg} \mathrm{DM} / \mathrm{con} /$ ngày. Lượng CP tiêu thụ đạt từ 1,87-3,34 kg/con/ngày, lượng $\mathrm{NDF}$ và $\mathrm{ADF}$ cao nhất ở $\mathrm{KP} 6(8,69$ và $5,13 \mathrm{~kg} / \mathrm{con} /$ ngày $)$ và thấp nhất ở KP7 (7,24 và $3,81 \mathrm{~kg} / \mathrm{con} /$ ngày). Các khẩu phần có lượng $\mathrm{EE}$ trung bình đạt $0,58 \mathrm{~kg} / \mathrm{con} / \mathrm{ngày}$, lượng NFC đạt từ 2,81-4,07 kg/con/ngày. Lượng ME tiêu thụ đạt từ $26,3-38,5 \mathrm{Mcal} / \mathrm{con} /$ ngày và lượng $\mathrm{NE}_{\mathrm{L}}$ đạt từ 16,1-24,1 Mcal/con/ngày, trung bình của các khẩu phần là $19,7 \mathrm{Mcal} / \mathrm{con} /$ ngày. KP6 có lượng $\mathrm{NE}_{\mathrm{L}}$ tiêu thụ cao nhất $(24,1$ 
$\mathrm{Mcal} /$ con/ngày), lượng $\mathrm{CP}, \mathrm{EE}, \mathrm{NDF}$ và $\mathrm{ADF}$ lần lượt là $3,34,0,87,8,69$ và $5,13 \mathrm{~kg} / \mathrm{con} /$ ngày. Về thành phần dưỡng chất tiêu thụ, hàm lượng $\mathrm{CP}$ đạt từ $11,8-18,7 \%$, trung bình của các khẩu phần là $15,4 \%$. Hàm lượng $\mathrm{NDF}$ và $\mathrm{ADF}$ dao động lần lượt là $47,7-54,8 \%$ và $26,6-32,0 \%$. Hàm lượng $\mathrm{EE}$ cao nhất ở KP8 với $4,95 \%$, tiếp đến là KP6 và KP9 (4,83-4,64\%). Hàm lượng NFC đạt từ 21,3-24,6\%, trung bình các khẩu phần đạt $22,5 \%$.

Chênh lệch duõ̃ng chất tiêu thụ so với tiêu chuẩn NRC (2001)

Theo Nguyễn Xuân Trạch và Mai Thị Thơm (2004), nguyên tắc chung khi tính nhu cầu cho bò vắt sữa là cung cấp đầy đủ các dinh dưỡng cần cho sự duy trì cơ thể, sản xuất sữa; ngoài ra còn phải cung cấp nhu cầu mang thai và tăng trọng (nếu có). Việc xác định tiêu chuẩn ăn cho bò là công việc khó khăn và phức tạp nên cách đơn giản nhất là dựa vào tiêu chuẩn có sẵn và đáng tin cậy. Đàn bò sữa điều tra thuộc giống bò lai HF, tầm vóc nhỏ và năng suất sữa thấp. Theo Lê Văn Phong và Nguyễn Văn Thu (2016), bò đang cho sữa của Cần Thơ có khối lượng trung bình dao động từ $424-468 \mathrm{~kg}$ (trung bình 446 $\mathrm{kg}$ ). Chính vì vậy, nhu cầu dinh dưỡng của NRC
(2001) cho bò sữa có khối lượng nhỏ $(450 \mathrm{~kg})$ được chọn làm qui chuẩn để so sánh và xây dựng khẩu phần hiệu chỉnh cho đàn bò khảo sát. Theo NRC (2001), bò có khối lượng cơ thể $450 \mathrm{~kg}$, giai đoạn giữa của chu kỳ cho sữa, năng suất sữa $15 \mathrm{~kg}$, mỡ sữa $4 \%$, đạm sữa $3,5 \%$ có nhu cầu cụ thể như sau:

\begin{tabular}{|c|c|}
\hline CP khẩu phần $(\%)$ & 13,9 \\
\hline NDF của khẩu phần tối thiểu $(\%)$ & 33,0 \\
\hline $\mathrm{ADF}$ của khẩu phần tối thiểu $(\%)$ & 21,0 \\
\hline EE của khẩu phần tối đa $(\%)$ & 7,00 \\
\hline NFC của khẩu phần tối đa $(\%)$ & 36,0 \\
\hline DM ăn vào ( $\mathrm{kg} /$ ngày) & 14,2 \\
\hline $\mathrm{NE}_{\mathrm{L}}$ ăn vào (Mcal/ngày) & 19,6 \\
\hline CP tiêu thụ ( $\mathrm{kg}$ DM/ngày) & 1,97 \\
\hline NDF tiêu thụ tối thiểu (kg DM/ngày) & 4,69 \\
\hline ADF tiêu thụ tối thiểu (kg DM/ngày) & 2,98 \\
\hline EE tiêu thụ tối đa (kg DM/ngày) & 0,99 \\
\hline NFC tiêu thụ tối đa (kg DM/ngày) & 5,11 \\
\hline
\end{tabular}

Từ tiêu chuẩn trên so sánh với Bảng 4 , ta có được sự chênh lệch $\mathrm{DM}, \mathrm{CP}$ và $\mathrm{NE}_{\mathrm{L}}$ tiêu thụ so với tiêu chuẩn NRC (2001) được thể hiện qua Bảng 5. Lượng NDF, ADF, EE và NFC tiêu thụ của bò ở các hộ chăn nuôi đáp ứng nhu cầu theo tiêu chuẩn.

Bảng 5. Chênh lệch dưỡng chất tiêu thụ so với tiêu chuẩn của NRC (2001)

\begin{tabular}{lccccccccccc}
\hline \multirow{2}{*}{ Tiêu thụ } & \multicolumn{10}{c}{ Khẩu phần } \\
\cline { 2 - 12 } & KP1 & KP2 & KP3 & KP4 & KP5 & KP6 & KP7 & KP8 & KP9 & KP10 & TB \\
\hline DM (kg/ngày) & 1,88 & 1,64 & $-0,05$ & 0,27 & 0,79 & 3,70 & $-1,00$ & 0,68 & 3,06 & 1,88 & 1,21 \\
CP (kg DM/ngày) & 0,29 & $-0,10$ & 0,14 & 0,00 & 0,44 & 1,37 & $-0,06$ & 0,52 & 1,04 & 0,46 & 0,41 \\
NE $_{\mathrm{L}}$ (Mcal/ngày) & 0,60 & $-0,71$ & $-2,16$ & $-1,75$ & 0,44 & 4,58 & $-3,42$ & 0,45 & 3,81 & $-0,05$ & 0,14 \\
\hline
\end{tabular}

Bảng 5 cho thấy lượng DM tiêu thụ của các khẩu phần đều cao hơn tiêu chuẩn NRC (2001) trừ KP3 và KP7. KP6 có lượng DM tiêu thụ cao hơn tiêu chuẩn $3,70 \mathrm{~kg} / \mathrm{ngày}$, tiếp đến là KP9 với 3,06 $\mathrm{kg} /$ ngày, trung bình DM tiêu thụ cao hơn tiêu chuẩn là $8,5 \%$. Riêng KP3 và $\mathrm{KP} 7$ thấp hơn tiêu chuẩn $(0,05$ và $1,00 \mathrm{~kg} /$ ngày). Lượng $\mathrm{CP}$ tiêu thụ của các khẩu phần cao hơn tiêu chuẩn nhưng cao hơn không nhiều, dao động từ $0,14-1,37 \mathrm{~kg} / \mathrm{ngày}$. Tuy nhiên, $\mathrm{KP} 2$ và $\mathrm{KP} 7$ có lượng $C P$ tiêu thụ thấp hơn $(0,1$ và $0,6 \mathrm{~kg} / \mathrm{ngày})$. Về $\mathrm{NE}_{\mathrm{L}}$ tiêu thụ, các KP1, KP5, KP6, $\mathrm{KP} 8$ và $\mathrm{KP} 9$ đều có $\mathrm{NE}_{\mathrm{L}}$ tiêu thụ cao hơn tiêu chuẩn NRC (2001), cao nhất là 4,58 Mcal/ngày. Các KP2, $\mathrm{KP} 3, \mathrm{KP} 4, \mathrm{KP} 7$ và $\mathrm{KP} 10$ có $\mathrm{NE}_{\mathrm{L}}$ tiêu thụ thấp hơn tiêu chuẩn, thấp nhất ở KP7 (3,42 Mcal/ngày). Nhìn chung, trung bình các khẩu phần có lượng $\mathrm{CP}, \mathrm{DM}$ và $\mathrm{NE}_{\mathrm{L}}$ tiêu thụ đáp ứng nhu cầu, tuy nhiên biến động hàm lượng dinh dưỡng trong khẩu phần là rất lớn tại mỗi hộ chăn nuôi. Thêm vào đó, mặt dù sử dụng nhiều phụ phẩm nông-công nghiệp chế biến cho bò ăn, nhưng khẩu phần chưa hợp lý, dẫn đến chi phí thức ăn còn khá cao (Bảng 7). Do đó, cần xây dựng mới các khẩu phần điều chỉnh dựa vào các nguồn thực liệu dễ tìm mà vẫn đáp ứng tốt nhu cầu dinh dưỡng theo tiêu chuẩn NRC (2001) và đồng thời cho chi phí thức ăn thấp hơn.

\subsection{Xây dựng khẩu phần điều chỉnh và so sánh chi phí thức ăn}

Các khẩu phần điều chỉnh được xây dựng nhằm cung cấp thông tin cho nông hộ về lượng ăn cần thiết của các thực liệu giúp đáp ứng nhu cầu dinh dưỡng của đàn bò, đồng thời cho năng suất và chất lượng sữa ổn định. Nguyên tắc xây dựng khẩu phần điều chỉnh là tăng việc sử dụng các nguồn thực liệu phụ phẩm dễ tìm, giảm việc sử dụng nhiều TĂHH và cỏ trong khẩu phần. Bảng 6 cho thấy các khẩu phần điều chỉnh đều đáp ứng đủ nhu cầu dinh dưỡng cho bò đang cho sữa theo tiêu chuẩn NRC (2001) và giảm $1.48 \mathrm{~kg} \mathrm{DM} \mathrm{TĂHH/con/ngày} \mathrm{so} \mathrm{với} \mathrm{khẩu} \mathrm{phần}$ đang được áp dụng (Bảng 3 ). Thức ăn hỗn hợp được xem xét giảm tỷ lệ trong khẩu phần điều chỉnh do giá thực liệu này ngày một tăng cao. Bã bia được sử dụng ở tất cả các khẩu phần điều chỉnh do có giá trị 
dinh dưỡng tốt, bò thích ăn, dễ tìm và giá rẻ. Cỏ tươi không được sử dụng hoặc sử dụng ở mức hạn chế do phần lớn nông hộ chăn nuôi bò ở thành phố Cần Thơ có rất ít và thậm chí một số nông hộ không có diện tích đất cho việc trồng cỏ. Các khẩu phần thức ăn điều chỉnh có giá dao động từ 3.765-4.416
$\mathrm{VNĐ/kg} \mathrm{DM.} \mathrm{Khẩu} \mathrm{phần} \mathrm{sử} \mathrm{dụng} \mathrm{mức} \mathrm{độ} \mathrm{cao} \mathrm{vỏ} \mathrm{và}$ cùi bắp ủ chua $(\mathrm{KP} 1 *$ và $\mathrm{KP} 2 *)$ có giá thức ăn thấp hơn so với khẩu phần sử dụng cỏ Voi hay thân và trái bắp ủ chua (KP3*, KP4*, KP5* và KP6*). Chi phí thức ăn của các khẩu phần điều chỉnh dao động từ 57.984-68.002 VNĐ/con/ngày.

Bảng 6. Khẩu phần điều chỉnh theo tiêu chuẩn của $\mathrm{NRC} \mathrm{(2001)}$

\begin{tabular}{|c|c|c|c|c|c|c|}
\hline \multirow{2}{*}{ Chỉ tiêu } & \multicolumn{6}{|c|}{ Khẩu phần điều chỉnh } \\
\hline & KP1* & KP2* & KP3* & KP4* & KP5* & KP6* \\
\hline \multicolumn{7}{|l|}{ Tỷ lệ thực liệu, \%DM } \\
\hline TĂHH & 25,0 & 25,0 & 25,0 & 25,0 & 25,0 & 25,0 \\
\hline Bã bia & 5,94 & 14,1 & 19,6 & 16,9 & 19,0 & 16,3 \\
\hline Bã đậu nành & 9,21 & - & - & - & - & - \\
\hline Cỏ Voi & - & - & - & 20,0 & 20,0 & 20,0 \\
\hline Vỏ khóm ủ chua & - & 7,68 & - & 10,0 & - & 10,0 \\
\hline Thân và trái bắp ủ chua & - & - & 55,4 & 0,0 & 36,0 & - \\
\hline Vỏ và cùi bắp ủ chua & 59,8 & 53,3 & - & 28,1 & - & 28,7 \\
\hline$\sum \mathrm{TĂH} H+\mathrm{TĂ}$ bổ sung $\mathrm{CP}^{(1)}, \%$ & 40,2 & 39,1 & 44,6 & 41,9 & 44,0 & 41,3 \\
\hline$\sum$ thức ăn thô xơ, \% & 59,8 & 60,9 & 55,4 & 58,1 & 56,0 & 58,7 \\
\hline \multicolumn{7}{|l|}{ Thức ăn tiêu thụ, kg DM/con/ngày } \\
\hline TĂHH & 3,85 & 3,85 & 3,85 & 3,85 & 3,85 & 3,85 \\
\hline Bã bia & 0,91 & 2,17 & 3,02 & 2,60 & 2,93 & 2,50 \\
\hline Bã đậu nành & 1,42 & - & - & - & - & - \\
\hline Cỏ Voi & - & - & - & 3,08 & 3,08 & 3,08 \\
\hline Vỏ khóm ủ chua & - & 1,18 & - & 1,54 & - & 1,54 \\
\hline Thân và trái bắp ủ chua & - & - & 8,53 & - & 5,54 & - \\
\hline Vỏ và cùi bắp ủ chua & 9,22 & 8,20 & - & 4,33 & - & 4,43 \\
\hline Tổng cộng & 15,4 & 15,4 & 15,4 & 15,4 & 15,4 & 15,4 \\
\hline \multicolumn{7}{|l|}{ Tồng dưỡng chất tiêu thụ } \\
\hline $\mathrm{CP}, \mathrm{kgDM} /$ ngày & 2,14 & 2,14 & 2,13 & 2,14 & 2,15 & 2,13 \\
\hline $\mathrm{CP}$ khẩu phần, \%DM & 13,9 & 13,9 & 13,8 & 13,9 & 13,9 & 13,8 \\
\hline $\mathrm{NE}_{\mathrm{L}}, \mathrm{Mcal} /$ ngày & 19,5 & 19,4 & 19,7 & 19,4 & 19,5 & 19,4 \\
\hline $\mathrm{NE}_{\mathrm{L}}$ khẩu phần, Mcal/kg DM & 1,27 & 1,26 & 1,28 & 1,26 & 1,27 & 1,26 \\
\hline NDF, kgDM/ngày & 7,80 & 7,93 & 8,98 & 8,15 & 8,85 & 8,16 \\
\hline NDF, $\%$ & 50,6 & 51,5 & 58,3 & 52,9 & 57,4 & 53,0 \\
\hline $\mathrm{ADF}, \mathrm{kgDM} /$ ngày & 4,75 & 4,77 & 4,94 & 4,81 & 4,98 & 4,82 \\
\hline $\mathrm{ADF}, \%$ & 30,8 & 31,0 & 32,1 & 31,3 & 32,3 & 31,3 \\
\hline \multicolumn{7}{|l|}{ Thức ăn tiêu thụ, kg tươi/con/ngày } \\
\hline TĂHH & 4,30 & 4,30 & 4,30 & 4,30 & 4,30 & 4,30 \\
\hline Bã bia & 3,82 & 9,05 & 12,6 & 10,9 & 12,2 & 10,5 \\
\hline Bã đậu nành & 9,34 & - & - & - & - & - \\
\hline Cỏ Voi & - & - & - & 18,6 & 18,6 & 18,6 \\
\hline Vỏ khóm ủ chua & - & 9,84 & - & 12,8 & - & 12,8 \\
\hline Thân và trái bắp ủ chua & - & - & 41,1 & - & 26,7 & - \\
\hline Vỏ và cùi bắp ủ chua & 41,3 & 36,7 & - & 19,4 & - & 19,8 \\
\hline Giá thức ăn, VND/kg DM & 3.795 & 3.765 & 4.404 & 4.147 & 4.416 & 4.127 \\
\hline Chi phí thức ăn, VNĐ/con/ngày & 58.444 & 57.984 & 67.815 & 63.865 & 68.002 & 63.552 \\
\hline
\end{tabular}

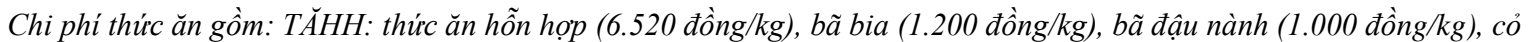
Voi (500 đồng/kg), vỏ khóm ủ chua (450 đồng/kg), thân và trái bắp ủ chua (600 đồng/kg), vỏ và cùi bắp ủ chua (400 đồng/kg). $K P^{*}:$ khẩu phần điều chỉnh. ${ }^{(1)}$ bã bia + bã đậu nành. 
Bảng 7. Chênh lệch chi phí thức ăn (VNĐ/con/ngày) giữa khẩu phần điều chỉnh và khẩu phần đang áp dụng tại nông hộ

\begin{tabular}{crrrrrrr}
\hline \multirow{2}{*}{$\begin{array}{c}\text { Khẩu phần } \\
\text { nông hộ }\end{array}$} & $\begin{array}{c}\text { Chi phí } \\
\text { thức ăn }\end{array}$ & \multicolumn{7}{c}{ Chênh lệch chi phí thức ăn } \\
\cline { 3 - 8 } KP1* & KP2* & KP3* & KP4* & KP5* & KP6* \\
\hline KP1 & 72.038 & -13.594 & -14.054 & -4.223 & -8.173 & -4.036 & -8.486 \\
KP2 & 63.336 & -4.892 & -5.352 & 4.479 & 529 & 4.666 & 216 \\
KP3 & 75.588 & -17.143 & -17.603 & -7.773 & -11.723 & -7.585 & -12.035 \\
KP4 & 63.647 & -5.203 & -5.663 & 4.168 & 218 & 4.355 & -95 \\
KP5 & 81.949 & -23.505 & -23.965 & -14.134 & -18.084 & -13.947 & -18.397 \\
KP6 & 85.125 & -26.681 & -27.141 & -17.310 & -21.260 & -17.123 & -21.573 \\
KP7 & 71.358 & -12.914 & -13.374 & -3.543 & -7.493 & -3.356 & -7.806 \\
KP8 & 66.825 & -8.381 & -8.841 & 989 & -2.961 & 1.177 & -3.273 \\
KP9 & 73.321 & -14.877 & -15.337 & -5.507 & -9.457 & -5.319 & -9.769 \\
KP10 & 79.351 & -20.906 & -21.366 & -11.536 & -15.486 & -11.348 & -15.798 \\
\hline TB & 73.254 & -14.810 & -15.269 & -5.439 & -9.389 & -5.251 & -9.702 \\
\hline
\end{tabular}

Chi phí thức ăn được tính tù TăHH (6.520 đồng/kg), bã bia (1.200 đồng/kg), bã đậu nành (1.000 đồng/kg), bã mì (1.000 đồng/kg), chuối chín loại (200 đồng/kg), cỏ Voi (500 đồng/kg), vỏ khóm ủ chua (450 đồng/kg), thân và trái bắp ủ chua (600 đồng/kg), vỏ và cùi bắp ủ chua (400 đồng/kg), KP*: khẩu phần điều chỉnh, TB: trung bình.

Bảng 7 cho thấy khẩu phần của các nông hộ đều có chi phí thức ăn khá cao, trung bình 73.254 $\mathrm{VNĐ/con/ngày.} \mathrm{Chi} \mathrm{phí} \mathrm{thức} \mathrm{ăn} \mathrm{của} 6$ khẩu phần điều chỉnh đều thấp hơn chi phí thức ăn trung bình của các hộ chăn nuôi, thấp nhất là $\mathrm{KP} 1 *(-20,2 \%)$ và $\mathrm{KP} 2 *(-20,8 \%)$. Khẩu phần $\mathrm{KP} 3 *-\mathrm{KP}^{*}$ giảm chi phí thức ăn so với trung bình của 10 nông hộ là $7,17-13,2 \%$. Với năng suất sữa trung bình là 13,2 $\mathrm{kg} / \mathrm{con} / \mathrm{ngày} \mathrm{và} \mathrm{giá} \mathrm{sữa} \mathrm{bò} \mathrm{loại} 1$ được thu mua hiện nay của nhà máy Vinamilk là $14.000 \mathrm{VNĐ} / \mathrm{kg}$ thì tiền bán sữa là $184.080 \mathrm{VNĐ/con/ngày.} \mathrm{Trừ} \mathrm{chi} \mathrm{phí}$ thức ăn thì hộ chăn nuôi thu được 111.546 $\mathrm{VNĐ/con/ngày.} \mathrm{Nếu} \mathrm{áp} \mathrm{dụng} \mathrm{khẩu} \mathrm{phần} \mathrm{điều} \mathrm{chỉnh}$ $\mathrm{KP} 1$ * và KP2* thì thu lợi nhuận lần lượt là 125.636 và $126.096 \mathrm{VNĐ/con/ngày} \mathrm{(tăng} \mathrm{14.090-14.550}$ $\mathrm{VNĐ/con/} \mathrm{ngày).} \mathrm{Điều} \mathrm{này} \mathrm{cho} \mathrm{thấy} \mathrm{sử} \mathrm{dụng} \mathrm{các}$ khẩu phần điều chỉnh sẽ mang lại hiệu quả kinh tế cao hơn so với các khẩu phần mà hộ chăn nuôi đang sử dụng. Tuy nhiên, tuỳ theo tình hình biến động của giá cả và sản lượng nguồn thức ăn mà nông hộ có thể lựa chọn khẩu phần điều chỉnh phù hợp nhất.

\section{KÊT LUẬN VÀ ĐỀ NGH!̣}

\subsection{Kết luận}

Đàn bò sữa nuôi tại nông hộ thành phố Cần Thơ có năng suất khá tốt và hàm lượng dưỡng chất trong sữa cao. Đàn bò sữa đang tiêu thụ thừa lần lượt $\mathrm{DM}$ là $1,21 \mathrm{~kg} /$ ngày, $\mathrm{CP}$ là $0,41 \mathrm{~kg} /$ ngày và $\mathrm{NE}_{\mathrm{L}}$ là 0,14 Mcal/ngày, tuy nhiên các giá trị này biến động rất lớn giữa các hộ chăn nuôi khác nhau. Điều này dẫn đến năng suất và thành phần sữa có nhiều biến động giữa các cá thể và nhóm bò nuôi ở nông hộ. Chi phí thức ăn cho bò còn tương đối cao ở nông hộ. Các khẩu phần điều chỉnh sử dụng các thực liệu dễ tìm đáp ứng đủ nhu cầu dinh dưỡng cho bò sữa theo tiêu chuẩn của NRC năm 2001 và giảm chi phí thức ăn từ $7,17-20,8 \%$.

\section{2. Đề nghị}

Thông tin và khuyến cáo các hộ chăn nuôi bò sữa áp dụng và đánh giá hiệu quả thực tế của các khẩu phần điều chỉnh lên năng suất của gia súc và hiệu quả kinh tế.

\section{TÀI LIỆU THAM KHẢO}

AOAC. (1990). Offical methods of analysis (15 th ed.). Association of official analytical chemists.

Belibasakis, N. G., \& Tsirgogianni, D. (1996). Effects of wet brewers grains on milk yield, milk composition and blood components of dairy cows in hot weather. Animal feed science and technology, 57(3), 175-181. https://doi.org/10.1016/0377-8401(95)00860-8

Đinh Văn Mười, Vũ Chí Cương \& Bùi Thu Trang. (2011a). Thành phần hóa học, tỷ lệ tiêu hóa in vivo, giá trị năng lượng, protein của thức ăn năng lượng và thức ăn bổ sung protein cho gia súc nhai lại. Tạp chí Khoa học Công nghệ Chăn nuôi, 33, 49-62.

Đinh Văn Mười, Vũ Chí Cương, Phạm Bảo Duy \& Bùi Thu Trang. (2011b). Thành phần hóa học, tỷ lệ tiêu hóa in vivo, giá trị năng lượng và protein của một số loại thức ăn thô xanh, thô khô, phụ phẩm trồng trọt và thức ăn ủ chua. Tạp chi Khoa học Công nghệ Chăn nuôi, 33, 34-48.

Hanuš, O., Samková, E., Křížová, L., Hasoňová, L. \& Kala R. (2018). Role of fatty acids in milk fat and the influence of selected factors on their variability-a review. Molecules, 23(7), 1636. https://doi.org/10.3390/molecules23071636. 
Jayanegara, A., Ridla, M., Nahrowi \& Laconi, E. B. (2019). Estimation and validation of total digestible nutrient values of forage and concentrate feedstuffs. IOP Conference Series: Materials Science and Engineering. 546(4), 042016 http://doi.org/10.1088/1757899X/546/4/042016.

Lã Văn Kính. (2003). Thành phần hóa học và giá trị dinh dưỡng của các loại thức ăn gia súc Việt Nam. NXB Nông nghiệp.

Lâm Phước Thành. (2021). Khảo sát cơ cấu đàn, năng suất và chất lượng sữa của đàn bò sữa tại trang trại Farm Milk Cần Thơ. Tạp chi Khoa hoc Trưòng Đại hoc Cần Tho, 57(1B), 85-92. https://doi.org/10.22144/ctu.jvn.2021.012

Lê Thụy Bảo Quỳnh. (2011). Sụ liên kết đa hình di truyền gen Leptin với năng suất và chất luợng sũa của giống bò Lai Holstein Friesian ở đồng bằng sông Cửu Long (luận văn thạc sĩ). Trường Đại học Cần Thơ.

Lê Văn Phong \& Nguyễn Văn Thu. (2016). Điều tra về sinh trưởng, sản xuất và kĩ thuật nuôi bò sữa tại nông trường sông Hậu, hợp tác xã bò sữa Long Hòa và Evergrowth ở đồng bằng sông Cửu Long. Tạp chi Khoa hoc Truò̀ng Đại hoc Cần Tho, 2, 48-55. https://doi.org/10.22144/ctu.jsi.2016.043

Lục Nhật Huy. (2016). Hiện trạng chăn nuôi và ảnh huớng của khẩu phần thức ăn đến năng suất, chất lương sũa và hệ vi sinh vật dạ cỏ của bò sũa tại hợp tác xã Evergrowth tỉnh Sóc Trăng (luận văn thạc sĩ). Trường Đại học Cần Thơ.

Lục Nhật Huy, Nguyễn Văn Hớn \& Nguyễn Trọng Ngữ. (2016). Khảo sát tình hình chăn nuôi bò sữa và nguồn thức ăn cho gia súc tại hợp tác xã Evergrowth, tỉnh Sóc Trăng. Tap chi Khoa hoc Kĩ thuật Chăn nuôi, 205, 71-77.

Nguyễn Hoàng Nhẩn. (2013). Khảo sát tình hình chăn nuôi và bệnh viêm vú trên đàn bò sũa tại hơp tác xã bò sũa Long Hòa thành phố Cần Tho (luận văn thạc sĩ). Trường Đại học Cần Thơ.

Nguyễn Nhựt Xuân Dung, Lưu Hữu Mãnh \& Nguyễn Thị Mộng Nhi. (2007). Thành phần hóa học và giá trị dinh dưỡng của một số giống cây thức ăn gia súc họ hòa thảo và họ đậu trồng tại thành phồ Cần Thơ. Tap chi Khoa hoc Trương Đại học Cần Tho, 7, 183-192.

Nguyễn Xuân Trạch \& Đinh Văn Cải. (2008). Dinh duõ̃ng và thức ăn trong chăn nuôi bò sũa. Dự án bò sữa Việt-Bỉ.

Nguyễn Xuân Trạch \& Mai Thị Thơm. (2004). Giáo trình chăn nuôi trâu bò (dành cho học viên cao học ngành Chăn nuôi). NXB Nông nghiệp.

NRC. (2001). Nutrient requirements of dairy cattle ( $7^{\text {th }}$ ed.). National academy press.

TCVN 3577:1981 (1981). Trâu bò sũa - kiểm tra năng suất sũa. https://vanbanphapluat.co/tcvn3577-1981-trau-bo-sua-kiem-tra-nang-suat-sua

Van Soest, P. J., Robertson, J. B., \& Lewis, B.A. (1991). Methods for dietary fiber, neutral detergent fiber and non-starch polysaccharides in relation to animal productinon. Journal of Dairy Science, 74(10), 3583-3597. https://doi.org/10.3168/jds.S00220302(91)78551-2

Viện Chăn nuôi. (1995). Thành phần và giá trị dinh duỡng thức ăn gia súc, gia cầm Việt Nam. NXB Nông nghiệp.

Vũ Chí Cương, Lê Minh Lịnh, Đinh Văn Tuyền \& Nguyễn Viết Đôn. (2011). Xác định nhu cầu năng lượng cho duy trì của bò sữa lai $3 / 4 \mathrm{HF}$ nuôi tại Việt Nam bằng các thí nghiệm nuôi dưỡng trên đàn bò cái vắt sữa (sau lứa đẻ 2 , tháng sữa 3 5). Tạp chí Khoa hoc Công nghệ Chăn nuôi, 30, 15-31.

Weiss, W. P., \& Tebbe, A. W. (2019). Estimating digestible energy values of feeds and diets and integrating those values into net energy systems. Translational Animal Science, 3(3), 953-961. https://doi.org/10.1093/tas/txy119

Younker, R. S., Winland, S. D., Firkins, J.L. \& Hull B. L. (1998). Effects of replacing forage fiber or nonfiber carbohydrates with dried brewers grains. Journal of Dairy Science, 81(10), 26452656. https://doi.org/10.3168/jds.S00220302(98)75822-9 